\title{
A VIRGEM E O MENINO
}

(Retrato natalino de Santo Afonso Maria de Ligório)

Ângelo Antônio Dallegrave

Paraná

Suspensa do céu

Cessou a harmonia,

Que a Cristo, Maria,

Cantando ninou.

Seu lábio divino,

A intacta donzela

Que vence a estrêla

Em graça, entoou:

"Meu Deus, meu tesouro,

"Meu filho, meu santo,

"Tu dormes, no entanto

"Eu morro de amor.

"Dormente, a tua mãe,

"Jesus, já não fitas?...

"A auras benditas

"Me abrasam de ardor.

"Se já êsses olhos

"Cerrados me ferem,

"Despertos, não querem

"Ferir-me também?...

"Ó róseo rostinho,

"Meu peito arrebatas!

"Ai! Deus que me matas,

"Eu morro, meu bem. 
"Forçoso é beijar-te,

"O lábio escolhido!...

"Perdoa, querido,

"Conter-me, não vou".

Calou, e no seio

O filho apertando,

Seu Deus afagando,

Lhe a bôca beijou.

Jesus, acordado,

Amante, ditoso,

Os olhos, gracioso,

Nos dela fitou.

Maria, êsse olhar,

Só essa mirada,

Foi dardo, ai! espada,

Que em ti se cravou!... 